Robert Almeder (Ed.)

Rescher Studies

A Collection of Essays on the Philosophical Work of Nicholas Rescher 


\title{
READING RESCHER
}

\author{
Volume 2
}


Robert Almeder (Ed.)

\section{Rescher Studies}
A Collection of Essays on the Philosophical Work of Nicholas Rescher

Presented to Him on the Occasion of His $80^{\text {th }}$ Birthday

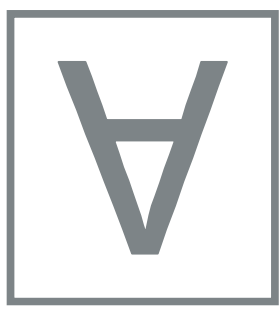

ontos

verlag 


\title{
Bibliographic information published by the Deutsche Nationalbibliothek
}

The Deutsche Nationalbibliothek lists this publication in the Deutsche Nationalbibliografie; detailed bibliographic data are available in the Internet at http://dnb.d-nb.de.

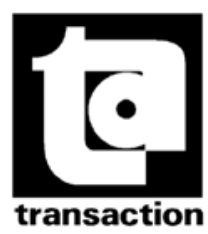

\author{
North and South America by \\ Transaction Books \\ Rutgers University \\ Piscataway, NJ 08854-8042 \\ trans@transactionpub.com
}

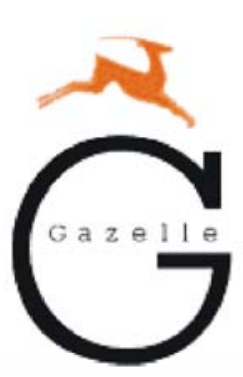

United Kingdom, Ireland, Iceland, Turkey, Malta, Portugal by

Gazelle Books Services Limited

White Cross Mills

Hightown

LANCASTER, LA1 4XS

sales@gazellebooks.co.uk

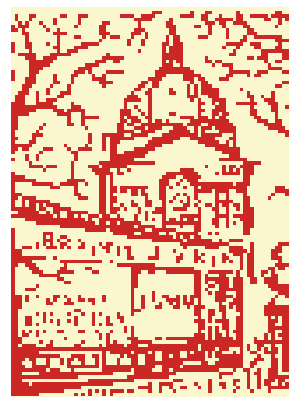

Livraison pour la France et la Belgique:

Librairie Philosophique J.Vrin

6 , place de la Sorbonne ; F-75005 PARIS

Tel. +33 (0)1 43540347 ; Fax +33 (0)1 43544818

www.vrin.fr

\author{
(C)2008 ontos verlag \\ P.O. Box 15 41, D-63133 Heusenstamm \\ www.ontosverlag.com
}

ISBN 13: 978-3-938793-97-8

2008

No part of this book may be reproduced, stored in retrieval systems or transmitted in any form or by any means, electronic, mechanical, photocopying, microfilming, recording or otherwise without written permission from the Publisher, with the exception of any material supplied specifically for the purpose of being entered and executed on a computer system, for exclusive use of the purchaser of the work

Printed on acid-free paper

This hardcover binding meets the International Library standard

Printed in Germany

by buch bücher $\mathbf{d d}$ ag 